\title{
TENURE AS A MODERATOR BETWEEN AFFECTIVE COMMITMENT AND PROACTIVELY
}

\author{
Sania Usmani ${ }^{1}$ \\ Iqra University \\ Kalpina Kumari ${ }^{2}$ \\ Iqra University \\ Siraj Jamal Siddiqui ${ }^{3}$ \\ Iqra University
}

\begin{abstract}
Purpose: This study tested the moderation of tenure between affective commitment and proactive work behavior in Karachi, Pakistan.

Methodology/Sampling: The method of gathering the data was primary research. The respondents were managers from pharmaceutical, banking, education and textile sector. The respondents were managers working as permanent employees in middle level or senior level management positions. The sample selection technique was non probability based in which non-restricted sampling type was used. The sample size comprised of 1000 respondents, 250 from each sector but data from 697 respondents was usable in the analysis.

Findings: The results showed that as the career progresses from trial stage towards stabilization and ultimately towards maintenance stage, employees are more emotionally committed with their organization and are keenly involved in proactive work behaviors.

Practical Implications: This study has inculcated the theoretical assumption that committed employees are creative and innovative and tend to demonstrate much more profound behaviors of proactivity than non-committed ones.
\end{abstract}

Keywords: tenure, affective commitment, proactive work behavior

\footnotetext{
* The material presented by the author does not necessarily portray the viewpoint of the editors and the management of the Institute of Business \& Technology (IBT)

1 Sania Usmani

2 Kalpina Kumari

3 Siraj Jamal Siddiqui

: Sania@iqra.edu.pk

: kalpina@iqra.edu.pk

(C) IBT-JBS is published by the Institute of Business and Technology (IBT).

Main Ibrahim Hydri Road, Korangi Creek, Karachi-75190, Pakistan.
} 


\section{INTRODUCTION}

The traditional view of individual performance needs to be reconsidered due to the continuous changes in firms, markets, products, and processes (Ilgen \& Pulakos, 1999). There is a constant requirement by organizations to implement effective mechanisms to ensure such active and initiating behaviors to increase performance and profitability for all its stakeholders. Proactivity thus must become a norm. If employees feel less committed to their organization, they disengage from discretionary behaviors. Non-Proactive behavior is the consequence of such lack of commitment. Besides tenure plays a major role in influencing commitment and proactive behaviors of employees. Tenure helps shape employees' attitudes toward their jobs so one can say that as number of years in an organization increases along with an upward trend in his/her career progress then it will affect their attitudes and behaviours on the job (Rogers, Clow and Kash, 1994).

In this study, tenure has been taken as a moderator between affective commitment and proactive work behaviours i.e. whether affective commitment increases or decreases employees' tendency to engage in proactive behaviour with the passage of time or not. Hence, this research analyses whether tenure moderates or strengthens this direct relationship or not.

\subsection{Hypotheses}

H1: Tenure moderates the relationship between affective commitment and proactive behavior.

Figure 1: Hypothesized Model

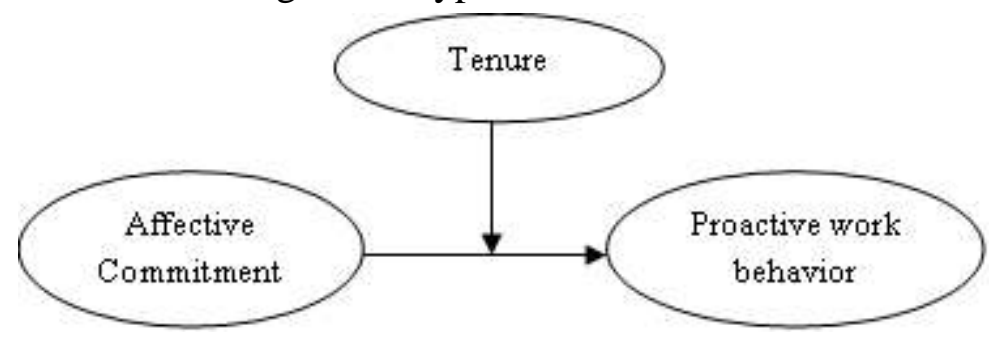

\section{LITERATURE REVIEW}

\subsection{Proactive Work Behavior}

In the present day, researchers favor the actively participating employee. Scholars and practitioners now view individuals as active representatives of an organization who have the ability to act proactively to bring positive changes not only in them, but also in their organizational setting (Grant \& Ashford, 2008). Proactive behaviors involve taking initiative and changing or creating new situations for improvements (Fritz \& 
Grant \& Ashford, 2008).

In light of the increasing popularity of proactive work behaviours, there has been substantial development in this area. Variety of concepts explaining proactivity has emerged which include proactive personality (Crant, 1995); personal initiative and taking charge (Morrison and Phelps, 1999) and general proactive behavior presented by Parker, Williams, and Turner (2006) and Grant and Ashford (2008). A latest advancement in the integrative research of proactive behaviors has been put forward by Parker and Collins (2010). They suggested that proactive work behavior is a latent variable which includes taking charge, individual innovation, problem prevention and voice that constitute proactive work behavior. This research has taken the work of Parker and Collins (2010) and taken proactive work behavior as a secondorder factor. Taking charge refers to bringing about functional change in the organization which effects how tasks are accomplished (Morrison \& Phelps, 1999; Parker \& Collins, 2010). Voice is related with communication regarding the problems that impacts one's work along with looking for information regarding such problems (Van Dyne \& LePine, 1998; Parker \& Collins, 2010). Individual innovation emphasizes on uniqueness. It comes about once an employee identifies new chances; develop new concepts, and implements them (Scott \& Bruce, 1994; Parker \& Collins, 2010). Lastly, problem prevention strives to ascertain the underlying source of problems, and focuses on managing the reoccurrence of obstacles in the work.

\subsection{Affective Commitment}

The foundation of affective commitment comes from organizational commitment. Organizational commitment is defined in terms of how strongly an employee identifies himself with and involves with organization. Allen \& Meyer (1990) defined organizational commitment in terms of a three component model. In their model, the three underlying constructs of organizational commitment were distinguished as affective, normative and continuance. The emotional attachment towards the organization as a result of the alignment between the organizational and personal values and aims is known as affective commitment. Affective commitment has the strongest positive relationship with employee well-being. Affective commitment is a psychological condition which may lead to decreased mental efforts and competence and increased employee turnover (Meyer, Stanley, Herscovitch, Topolnytsky, 2002).

\subsection{Affective commitment and Proactive Work Behavior}

Recently, literature on affective commitment has shed light on the relationship between Affective Commitment and proactive behavior. Some proclaim that most variability in proactive behavior is attributable to affective commitment (Den Hartog \& Belschak, 2007), while others recommend affective commitment is linked to generalized compliance rather than proactive behavior (Parker et al., 2006). Discretionary work behavior of employees is enhanced with increased affective commitment. Committed employees think of their organizations success as their own and want to stay with the organization therefore they put in extra effort a pre-condition of exerting 
committed and thus proactive behavior will spread from initial employees to other numerous employees (Spychala, 2010). Parker (2000) proposes that as a consequence of affective commitment, employees may put in extra effort in their work; either inactive or proactive way.

\subsection{Tenure}

Tenure is taken as the moderating variable in the model between affective commitment and proactive work behavior. Making reference to Super's (1957) careerstage model, these researchers proposed that a) employees in the early stage of their career are keen to identify their interests and capabilities, achieve a sense of mastery, and gain acceptance; b) employees in the middle career stage are keen to advance and grow professionally; and c) later-career-stage employees are keen to find challenging work assignments and more generally assume responsibility for mentoring others. Therefore tenure is taken in terms of three stages in this study, the "trial" stage (less than two years tenure), the "stabilisation" stage (two to ten years tenure and the "maintenance" stage (more than ten years) (Aryee et al., 1994).

Vandenberg and Self, (1993); and Ostroff and Kozlowski, (1993), Beck and Wilson (2000) proposed that the trial stage may last for a year, as affective commitment decreased after one year. These researchers also found that affective commitment decreased in the stabilization stage.

While English, Morrison \& Chalon, (2010) indicated in their study that affective commitment was greater in the later tenure.

The present research uses the three tenure categories namely: early, middle and later tenure where early tenure comprises of lesser than a year; middle or intermediate tenure consisted of one to nine years and later or advanced tenure involves greater than nine years.

\subsection{Tenure as a Moderator between Affective Commitment and Proactive Work Behavior}

There are two perspectives related to the effect of tenure on individual's behaviors and attitudes. The first perspective (Alutto \& Hrebiniak, 1975; Stevens, Janice, \& Harrison, 1978; Staw \& Ross, 1980) proposes that longer tenure is positively related to behaviors and attitudes. Employees who have worked for longer in the organization accept authority, policies and values (Schmidt \& Posner, 1983). Also, employees with long tenure were less inclined to search for better jobs in the market; they were highly motivated, and committed and showed greater participation in the organization and required job security (Rhoades \& Eisenberger, 2002).

On the other hand, the second perspective opposed to the aforementioned arguments indicate that rather shorter tenure employees are positive, passionate and accepting, about their work surroundings. The short tenure employees display high 
Bhargava, 2013).

According to some researchers affective commitment strengthens with tenure, while other researchers have concluded differently. For example (Morrow and McElroy, 1987; Gaertner and Nollen, 1989; Rhoades and Eisenberger, 2001) found that tenure is positively associated to affective commitment, while Lok and Crawford, (2001) showed that they are negatively related. Furthermore, Gellatly, (1995); Konovsky and Cropanzano, (1991); Reichers, (1986); and Bateman and Strasser, (1984) found no relationship between tenure and affective commitment.

\section{RESEARCH METHODOLOGY}

The method of gathering the data was primary research. The questionnaire used pre-developed questions taken from past studies. The respondents were managers from national and multinational organizations from pharmaceutical, banking, education and textile sector. The respondents were managers working as permanent employees in middle level or senior level management positions because it proactive behaviors would be more apparent in them as they typically possess adequate autonomy to involve in such behaviors. The sample selection technique was non probability based in which non-restricted sampling type was used. The population is unidentified as there would be thousands of managers in each sector. The sample size comprised of 1000 respondents, 250 from each sector. 214 questionnaires were usable from banking sector, 170 were usable from education sector, 173 respondents correctly filled from pharmaceutical sector and 140 returned the complete questionnaire from textile sector. Data from 697 respondents was used in analysis for all the variables and sub variables

\subsection{Measures}

Proactive work behavior was assessed using Parker et al., (2010) four measures namely; Taking charge, Voice, Individual innovation, and Problem prevention. Affective commitment construct was assessed through six questions which were established by Meyer, Allen and Smith (1993). All the measures used Likert scale which ranged from point 1 to 5, where, "1" labelled as Strongly Disagree to "5" labelled as Strongly Agree. In this study tenure was operationalized using three stages; early stage comprises of less than one year; middle stage having 1 to 9 years; and later stage having more than 9 years (English, Morrison \& Chalon, 2010). The question was asked from respondents as to select one option from these three to express their current tenure with the organization.

\section{RESULTS}

Data on 22 items was collected and were named as Tak_Char1, Tak_Char2, Tak_Char3, Voice1, Voice2, Voice3, Voice4, Ind_Inn1, Ind_Inn2, Ind_Inn3, Pro_Prev1, Pro_Pre2, Pro_Pre3, Aff_Com1, Aff_Com2, Aff_Com3, Aff_Com4, Aff_Com5, Aff_Com6, Gender, tenure, and Age in the SPSS data sheet. Table 1 represents the descriptive statistics and reliability estimates for proactive work behavior and affective 
Tenure as a Moderator Between Affective Commitment and Proactively

endogenous variables. Relationships among these variable were hypothesized as in Figure 1. The model is composed of affective commitment, proactive work behavior and tenure.

H1: Tenure moderates the relationship between affective commitment and proactive behavior.

For the assessment of this above stated hypothesis, preacher and Hayes 2011 process macro was run in SPSS 19 to calculate the moderated effect of tenure on proactive work behavior. Table 2 assesses the model and shows that, R square is 0.2773 which means that affective commitment explains $27.73 \%$ variation in proactive work behaviors. The F, dfs and $\mathrm{p}$ values indicate that the model of tenure, affective commitment and the interaction of tenure and affective commitment significantly predicts proactive work behaviors, $F(3,693)=88.6433$, with $p$ value $<0.001$ the next Table no. 3 explains the coefficients (coeff), standard deviations (se), $\mathrm{t}$ values, $\mathrm{p}$ values, the lower limit $95 \%$ confidence interval (LLCI) and the upper limit 95\% confidence interval (ULCI). The first place to look on this Table is at the $\mathrm{p}$ value for the interaction (int_1), which shows that the interaction of tenure and affective commitment is statistically significant $\mathrm{p}<0.05$ i.e. $\mathrm{p}=0.0352$, which means that the moderator is moderating the relationship between affective commitment and proactive work behavior and coefficient is 0.0853 . Also the upper and lower bounds explain that there is no zero between them and it is positive i.e. $\mathrm{LLCI}=0.0059$ and $\mathrm{ULCI}=0.1647$. Further, affective commitment has a positive and direct relationship with proactive work behavior at $p<0.001$, coefficient 0.3629 but there is no direct relationship of tenure and proactive work behavior as the $\mathrm{p}$ value $=0.3996>0.05$.

The last Table no. 4 explains the conditional effect of $\mathrm{X}$ on $\mathrm{Y}$ at the values of the moderator which is tenure. The values for the moderators are taken as the mean plus/minus one SD from mean. The first row shows when the tenure is -0.5571 , the second row shows when tenure is at mean (zero, as we centered the varibles around the mean), and the third row indicates when tenure is at 0.5571 . when tenure is low $\mathrm{b}=$ $0.3154,95 \%$ CI $(0.2545,0.3762), t=10.1769, \mathrm{p}<0.001$. When the tenure is at mean then, $b=0.3629,95 \% \mathrm{CI}(0.3188,0.4070), \mathrm{t}=16.1533, \mathrm{p}<0.001$. When the tenure is high, $\mathrm{b}=0.4104,95 \% \mathrm{CI}(0.3464,0.4744), \mathrm{t}=12.5838, \mathrm{p}<0.001$. All these values reflect that tenure moderates the relationship between affective commitment and proactive work behaviors.

\section{DISCUSSION AND CONCLUSION}

The moderated model tested whether the tenure affects the relationship between affective commitment and proactive work behavior. It was found that as employees progress in their career in their respective organizations, their commitment tends to increase with time. Thus supervisors, managers and HR executives should give them a safe and sound working environment to nurture their capabilities and enhance their potential, train them for uncertain situations and new technology which will boost their morale, and increase their loyalty and commitment towards their companies. Managers must also attempt to provide effective HR policies and practices, transparent information 
perspectives between employees and their supervisors with regard to proactive work behavior which may have implications for motivation, and performance evaluations as supervisors may reward this behavior.

\section{REFERENCES}

Agarwal, U. A., \& Bhargava, S. (2013). Effects of Psychological Contract Breach on Organizational Outcomes: Moderating Role of Tenure and Educational

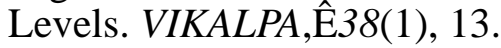

Allen, N. J., \& Meyer, J. P. (1990). The measurement and antecedents of affective, continuance, and normative commitment to the organization. Journal of Occupational Psychology, 63, 1-18.

Alutto, J. A., \& Hrebiniak, L. G. (1975). Research on commitment to employing organizations: Preliminary findings on a study of managers graduating from engineering and MBA programs. Academy of Management meetings, New Orleans.

Aryee, S., Chay, Y.W. and Chew, J. (1994). An investigation of the predictors and outcomes of career commitment in three career stages. Journal of Vocational Behaviour, 44, 1-16.

Bateman, T. S., \& Strasser, S. (1984). A longitudinal analysis of the antecedents of organizational commitment. $\hat{E}$ Academy of management journal,27(1), 95-112.

Beck, N. \& Wilson, J. (2000). Development of affective organizational commitment:A cross ehaviorl examination of change with tenure. Journal of Vocational Behaviour. 56, 114-136.

Crant, J. M. (1995). The Proactive Personality Scale and objective job performance among real estate agents. Journal of Applied Psychology, 80, 532-537.

Coyle-Shapiro, J. A-M. (2002). A psychological contract perspective on organizational citizenship behaviour. Journal of Organizational Behaviour, 23(8), 927-946.

Cropanzano, R., James, K., \& Konovsky, M. A. (1993). Dispositional affectivity as a predictor of work attitudes and job performance. Journal of Organizational Behaviour, 14(6), 595-606.

Den Hartog, D. N., \& Belschak, F. D. (2007). Commitment, affect and initiative at work. Journal of Occupational and Organizational Psychology, 80, 601-622.

English, B., Morrison, D., \& Chalon, C. (2010). Moderator effects of organizational tenure on the relationship between psychological climate and affective commitment. Journal of Management Development, $\hat{\mathrm{E}} 29(4), 394-408$. 
Fritz, C., \& Sonnentag, S. (2007). Antecedents of day-level proactive ehavior: A look at job stressors and positive affect during the workday.ÊJournal of Management.

Gaertner, K. N., \& Nollen, S. D. (1989). Career experiences, perceptions of employment practices, and psychological commitment to the organization. Human relations, $\hat{\mathrm{E}} 42(11)$, 975-991.

Gellatly, I. R. (1995). Individual and group determinants of employee absenteeism: Test of a causal model.ÊJJournal of organizational ehavior, $\hat{E} 16(5), 469-485$.

Grant, A. M., \& Ashford, S. J. (2008).The dynamics of proactivity at work. Research in Organizational Behaviour, 28, 3-34.

Helmreich, R. L., Sawin, L. L., \& Carsrud, A. L. (1986). The honeymoon effect in job performance: Temporal increases in the predictive power of achievement motivation. Journal of Applied Psychology, 71(2), 185-188.

Ilgen, D. R., \& Pulakos, E. D. (1999).ÊThe Changing Nature of Performance: Implications for Staffing, Motivation, and Development. Frontiers of Industrial and Organizational Psychology. Jossey-Bass Inc., Publishers, 350 Sansome Street, San Francisco, CA94104.

Konovsky, M. A., \& Cropanzano, R. (1991). Perceived fairness of employee drug testing as a predictor of employee attitudes and job performance.ÊJournal of applied psychology, $\hat{\mathrm{E}} 76(5), 698$.

Lok, P., \& Crawford, J. (2001). Antecedents of organizational commitment and the mediating role of job satisfaction.ÊJJournal of Managerial Psychology, $\hat{E} 16(8), 594-$ 613.

Meyer, J.P., Stanley, D.J., Herscovitch, L. \& Topolnytsky, L. (2002). Affective, Continuance, and Normative Commitment to the Organization: A Meta-analysis of Antecedents, Correlates, and Consequences. Journal of Vocational Behaviour, $61,20-52$.

Morrison, E. W., \& Phelps, C. C. (1999). Taking charge at work: Extrarole efforts to initiative workplace change. Academy of Management Journal, 42, 403-419.

Morrow, P. C., \& McElroy, J. C. (1987). Work commitment and job satisfaction over three career stages.EJournal of Vocational Behaviour, $\hat{E} 30(3), 330-346$.

Ostroff, C., \& Kozlowski, S. (1993). The role of mentoring in the information gathering processes of newcomers during early organizational socialization. Journal of Vocational Behaviour, 42, 170-183.

Parker, S. K. (2000). From passive to proactive motivation: The importance of flexible 
role orientations and role breadth self-efficacy. Applied Psychology: An International Review, 49, 447-469.

Parker, S. K., \& Collins, C. G. (2010). Taking Stock: Integrating and Differentiating Multiple Proactive Behaviours. Journal of Management, 36(3), 633-662.

Parker, S. K., Williams, H. M., \& Turner, N. (2006). Modeling the antecedents of proactive ehavior at work. Journal of Applied Psychology, 91, 636-652.

Rainey, H. G. (2003). Understanding and managing public organizations. Jossey-Bass Inc Pub.

Reichers, A. E. (1986). Conflict and organizational commitments. $\hat{E} J$ ournal of Applied Psychology, $\hat{\mathrm{E}} 71(3), 508$.

Rhoades, L., Eisenberger, R., \& Armeli, S. (2001). Affective commitment to the organization: the contribution of perceived organizational support. $\hat{\mathrm{E} J o u r n a l}$ of applied psychology, $\hat{\mathrm{E}} 86(5), 825$.

Rogers, J. D., Clow, K. E., \& Kash, T. J. (1994). Increasing job satisfaction of service personnel. Journal of Services Marketing, 8, (1), 14-26.

Scott, S. G., \& Bruce, R. A. (1994). Determinants of innovative ehavior: A path model of individual innovation in the workplace. Academy of Management Journal, 37, 580-607.

Schmidt, W. H., \& Posner, B. Z. (1983). Managerial values in perspective. AMA Membership Publications Division, American Management Associations.

Spychala, A., \& Sonnentag, S. (2011). The dark and the bright sides of proactive work behaviour and situational constraints: Longitudinal relationships with task conflicts. $\hat{E}$ European journal of work and organizational psychology,20 (5), 654680.

Staw, B. M., \& Ross, J. (1980). Commitment in an experimenting society: A study of the attribution of leadership from administrative scenarios. Journal of Applied Psychology, 65(3), 249

Stevens J. M., Janice M. B., Harrison M. T. (1978). Assessing personal, role, and organizational predictors of managerial commitment. The Academy of Management Journal, 21(3),380-396.

Super, D. (1957). The Psychology of Careers. Harper \& Row, New York, NY. Vandenberg, R. J., \& Self, R. M. (1993). Assessing newcomers' changing commitments to the organization during the first 6 months of work. Journal of Applied Psychology,78,557-568. 
Van Dyne, L., \& LePine, J. (1998). Helping and voice extra-role behaviours: Evidence of construct and predictive validity. Academy of Management Journal, 41, 108119.

Wright, T. A., \& Bonett, D. G. (2002). The moderating effects of employee tenure on the relation between organizational commitment and job performance: A metaanalysis. Journal of Applied Psychology, 87(6), 1183-1190.

\section{APPENDIX}

Table 1 Descriptive Statistics and Reliability Estimates

\begin{tabular}{|c|c|c|c|}
\hline Variable & Mean & SD & Alpha \\
\hline Proactive Work Behavior & 3.977 & 0.8838 & 0.814 \\
\hline Taking Charge & 4.1253 & .8233 & 0.616 \\
\hline Voice & 3.8153 & .9367 & 0.571 \\
\hline Individual Innovation & 4.0167 & .8668 & 0.675 \\
\hline Problem Prevention & 3.9493 & .9084 & 0.558 \\
\hline Affective Commitment & 3.9395 & .9614 & 0.842 \\
\hline
\end{tabular}

Table 2: Model Summary

\begin{tabular}{|ccccccc|}
\hline $\mathbf{R}$ & R-sq & MSE & F & df1 & df2 & p \\
\hline .5266 & .2773 & .1784 & 88.6433 & 3.0000 & 693.0000 & .0000 \\
\hline
\end{tabular}

Table 3: Model

\begin{tabular}{|llllccc|}
\hline & coeff & se & t & p & LLCI & ULCI \\
\hline constant & 3.9585 & .0162 & 243.9483 & .0000 & 3.9267 & 3.9904 \\
\hline Tenure & -0.0246 & .0292 & -.8429 & .3996 & -.0818 & .0327 \\
\hline affec & .3629 & .0225 & 16.1533 & .0000 & -.3188 & .4070 \\
\hline int_1 & .0853 & .0404 & 2.1098 & .0352 & .0059 & .1647 \\
\hline
\end{tabular}

Table 4: Conditional effect of $\mathrm{X}$ on $\mathrm{Y}$ at values of the moderator(s):

\begin{tabular}{|rrrrcrr|}
\hline Tenure & Effect & $\mathrm{se}$ & $\mathrm{t}$ & $\mathrm{p}$ & $\mathrm{LLCI}$ & $\mathrm{ULCI}$ \\
\hline-0.5571 & .3154 & .0310 & 10.1769 & .0000 & .2545 & .3762 \\
\hline 0.0000 & .3629 & .0225 & 16.1533 & .0000 & .3188 & .4070 \\
\hline 0.5571 & .4104 & .0326 & 12.5838 & .0000 & .3464 & .4744 \\
\hline
\end{tabular}

